\title{
SPECIAL OPERATIONS FORCES IN THE FIGHT AGAINST TERRORISM ON NATIONAL TERRITORY
}

\author{
Col. Plamen TORLAKOV
}

\begin{abstract}
This article presents basic definitions related to terrorism and examines the essence and main features of this phenomenon, as well as possible targets of terrorist actions. Based on official documents, the author presents the roles and the tasks of the Bulgarian Armed Forces in the fight against terrorism. In the focus of his examination is the employment of Special Operations Forces in the fight against terrorist units on the territory of the Republic of Bulgaria and the support, provided by all national organizations with counterterrorist missions to tactical groups.
\end{abstract}

Keywords: Counterterrorism, Special Operations Forces, Bulgarian Armed Forces, Ministry of the Interior, Land Forces, Special Antiterrorist Unit, Hostage Rescue Operations.

\section{Introduction}

We have witnessed significant changes in the system of international relations in recent years. As a result of the continued intensification of social, demographic and ecological frictions between large community groups, the end of the Cold War did not bring enhancement of security in a global context. The changes in the security environment placed terrorism and organized crime on front pages as major threats to international security. By and large, terrorism remains the only form currently used for achieving political aims through violence.

Particularly acute are the dangers of international terrorism, drug trafficking, illegal arms traffic and other forms of organized crime, which by their sheer scope turn into a global threat to peace. At the end of twentieth century all these combined emerged as one of the most negative consequences of globalization. In its capacity, organized international crime, and the international terrorism in particular, have a global nature. These wide-reaching problems of the day demand international consolidated reaction; their scale, sharpness and destructive power may have-if there are no adequate and timely preparedness, prevention, and response-catastrophic consequences. 
The events of September 11, 2001 in the United States, the hostage crisis in Moscow in October 2002, the bomb attacks in Tell Aviv, Grozny, Madrid, and London, the Beslan tragedy and many others confirm that international terrorism is the most serious threat to security today. The conditions for terrorist activities considerably improved with the advancement of democratic values, the development of communications and the easier movement of people and money. In order to achieve their aims, modern terrorists have vast financial, communication and human resources and are, possibly, capable of using radiological, chemical and biological weapons with considerable destructive power and huge psychological effect.

In his speech at the NATO-Russia conference in Moscow on 9 December 2002, the then NATO Secretary General Lord Robertson not only recognized, but emphasized the role of the military in the fight against terrorism ${ }^{1}$ :

Many analysts have stressed the importance of non-military tools - freezing terrorist financing; coordinating police work; tighter border controls; better inspection of shipping containers; and improved intelligence sharing. Let there be no doubt these analysts are right. Non-military tools are crucial to winning this struggle, and to ignore them is to fail in our common endeavour.

But the military, too, must play its part ...

NATO should also be ready to act in support of the international community's efforts against terrorism. ... To meet these demanding requirements, NATO is taking concrete and immediate steps to modernise our military forces. ... NATO is on its way to becoming a much more effective partner in the international community's response to $21^{\text {st }}$ Century threats.

\section{Definition, Essence and Characteristics of Terrorism}

From a methodological point of view, it is important to define with maximum precision the essence and content of the term "terrorism." The definition of terrorism is in close relation to its essence as a phenomenon in social life. Thus, the definition and the essence are regarded as an entity. The United Nations took into consideration the problem of the exact and thorough definition of the term "terrorism," which brought about the need of establishing a new Counter-Terrorism Committee. ${ }^{2}$ Another reason behind this work is the frequent interference into the practical work of competent services in cases of clearly criminal offences involving murdering or hurting of people, destruction, or crimes committed out of political motives.

Researchers of the phenomenon "terrorism" are unanimous that these activities are criminal acts/ acts of violence, pursuing political goals.

The definition of "terrorism" closely reflects its nature of a social phenomenon, so its definition and essence are indivisible. Different authors and organizations still have not reached a unanimous definition, to be accepted as legitimate in legal theory and 
practice. Edward Herman, Emeritus Professor from Pennsylvania’s Wharton School of Business, has offered a politically neutral, straightforward definition of terrorism that is difficult to argue with: "the use of force or the threat of force against civilian populations to achieve political objectives.”3 Although quite succinct, this definition addresses the basic issues - the use of violence, civilian targets, and pursuit of political aims. The political motivation and objectives, pursued by the perpetrators of criminal acts, should be at the heart of the definition of "terrorism." Based on the analysis and comparison of various opinions, we adopted an approach in which terrorism is examined as a complicated political and legal phenomenon, founded in attempts to erode the political principles of governance in the states, targets of terrorist activity. Towards the achievement of this goal, terrorists strive to persuade the society that the government is unable to rule the country, to protect their security and the internal order.

Also, based on this first order definition, it is possible to look at terrorism as an international or national illegal, i.e. criminal activity, involving use of violence or threats of violence in order to achieve concrete political objectives and, most of all, to weaken and destabilize existing governments. Generally, this aspect of the definition may be summarized as follows: "Terrorism is a criminal act with political motives."

Approaching the definition of the term "terrorism" systematically, we need to delineate its essential characteristics as a phenomenon:

- Terrorism is one of the forms of organized violence and as such it is a socially dangerous phenomenon. Terrorists direct their activities towards elimination of people who are active, i.e. politicians, other public figures, military lawyers, etc., or to facilities, where usually there are many people or which are socially significant. Additionally, the means used by terrorists usually lead to death, very frequently of innocent citizens, while damage is huge. Denial of the notion of "innocence" is typical of terrorists; they think that everyone belonging to the society opposing them is guilty. With this sort of moral, victims of terrorist acts are frequently innocent people. Terrorists find particularly important syndromes caused by consequences of violence.

- Concrete political and/or ethno-separatist or religious-political aims are pursued through terrorism; the aims of the latter two can be regarded as political so far as terrorists strive to change a government, terrorist-separatists - to tear off territories from the mother-country, while those with religious motivation - to establish a theocracy. The main objective of terrorists is to destabilize or change the political system and the public power in the state of their activity. All researchers on terrorism are unanimous in regard to this aspect of the phenomenon. 
- There is trend towards more active ideological motivation behind terrorist acts. The motives of modern terrorist organizations are of ethno-nationalist, anarchic, religious or purely political nature. All terrorist organizations have ideological grounds and a platform, which make them different from one another and determine the direction of their activities. Something typical for their ideological platforms is the presence of extreme and radical ideas, aiming at changing the political system and public order in society and, on the other hand, justifying the use of violence in pursuing radical objectives.

- Terrorist organizations are solidly organized groups, which pursue their political goals using extreme violence or threat of violence. This fact sets the framework for establishing specific mechanisms and principles of preparation for the execution of the terrorist act itself. Terrorists adhere to one important principle in their activities, i.e. strictly detailed action planning, whereupon predicting and assessing different elements of the environment and the impact of eventual changes. On the other hand, the principle of conspiracy and secrecy during planning and executing terrorist acts is at the basis of their activities, even more so since terrorist organizations are illegal groups with nonlegitimate social characteristic.

- Terrorist activities rapidly proliferate. Terrorist organizations spread their activity all over the countries in the scope of their political goals, i.e. countries where acts of violence could weaken or destabilize the legal political authority and form of government.

- In their activities terrorist groups seek the effect of mass. For the purpose of achieving cardinal strategic aims, such as the change of political system and government, violence acts are naturally directed to targets of public importance such as buildings, persons, vehicles, etc. On the other hand, in order to shape societal opinion against the legal government, terrorists strive to provoke massive scare among the population in order to prove that the government is not capable of coping with the violence and of ensuring social order and safety. Towards this purpose, terrorists more and more frequently resort to unscrupulous choice of targets of their violence, trying to cause mass destruction and high number of victims, trying to achieve the syndrome of consequences of violence. In other words, terrorism as a phenomenon targets a circle of people wider than the set of its immediate opponents. We even think it would not be an exaggeration to state that terrorism is directed against the entire democratic society.

- The actions of terrorist organizations are systematic. Quite clearly, in order to succeed in reaching such complex variety of objectives terrorist organizations 
use violence systematically. This systematic approach is reflected in the planning of terrorist actions, their wide spread, and the pursuit of mass casualties.

- Terrorism is a symbiosis between the high level of terrorists' political motivation and the low level of participation of the population in the political process in the countries where violent acts are carried out. Terrorist acts are executed by small groups which clearly differentiates terrorism from national liberation movements. This differentiation is quite important from a methodological point of view. As a rule, terrorism does not have such a mass nature. On the other hand, liberation movements do not rely on mass destruction and murder. If they use indiscriminate violence, liberation movements would not be distinguished from terrorist organizations. The distinguishing feature of terrorism compared to other forms of political struggle-revolution, war, guerilla warfare, etc.-is the tactic of indiscriminate and unlimited violence, or threat of violence, over individuals or whole communities that fall as accidental victims of circumstances without being directly opposed to terrorists. On the other hand, terrorists usually try to evade direct clash with governmental authorities, such as the police, the military, paramilitary organizations, or special services. National liberation movements are more or less supported by the population (or considerable part of it) of the country where they are active. On the contrary, similar support in regard to terrorist organizations is not observed.

Given its complex and contradictory essence, modern terrorism turns into a social threat. It causes serious problems to internal and international politics and law. It should be noted that terrorists and organized crime groups often use the same methods to exercise their influence and to achieve concrete objectives. However, there is an essential difference between them. It can be summarized in the roots of terrorism, in the goals pursued by terrorists and, last but not least, in the results of terrorist acts, whereupon innocent people fall victim.

The main reason for the rise of terrorism is the rejection of the political system or of concrete political decisions. Usually, this main reason is the external act of a complex of clearly expressed or well-hidden claims of economic, religious, emotional, or social nature.

There are a number of criteria according to which terrorist actions can be categorized, among these are the preferred targets, used means, areas of activity and causes for terrorist actions. According to the ideological reasoning, terrorism can be left-orientated (uttermost left extremism), right-orientated (neo-Nazism, neo-Fascism), religious-nationalistic (ethnocentric, separatist), or religious-political. In regard to target setting, terrorist activities can be subdivided in aerial, maritime, or land. According to the 
means used for terrorist acts there are two major groups involving respectively weapons of mass destruction (nuclear, radiological, chemical, or biological) and conventional weapons (explosives, kinetic weapons, etc.).

The structure of a terrorist organization usually includes: leadership, combat groups and support groups. For most of them the number of terrorists is not over one hundred, but there are some exceptions, especially in structures, which operate under the disguise of national liberation movements.

Each terrorist organization has its special features related to the causes of its existence, the nature of its specific goals and tasks, as well as to the methods and means the organization implements. The choice of targets is especially important. It depends on the possible effect, expected reaction, and the accessibility of the target, e.g., the level of its protection. As a rule, terrorists seek and choose "easy" targets, the attack of which would have greatest possible impact.

\section{Roles and Tasks of the Bulgarian Armed Forces in the Fight against Terrorism}

Recently, we witnessed an increase of the responsibilities of the Bulgarian Armed Forces (BAF) in the fight against terrorism, weapon trafficking, illegal trafficking of drugs and people and the proliferation of weapons for mass destruction and dual-use equipment and technologies. Challenges are being turned into opportunities. The following activities seem to emerge as priority tasks in preparing BAF for the war on terrorism:

- Creation and introduction of an adequate normative base regulating the use of Special Operations Forces (SOF);

- Enhancement of SOF training, provision of special equipment and significant increase of their mobility;

- Advancing the command, control, communications and information systems in all units of the armed forces;

- Enhancing the medical support system that is to cope not only with acts of bio-terrorism, but also with all contagious diseases that potentially cause epidemics, as well as with scenarios involving high number of fatalities and injuries;

- Building up effective integrated intelligence to ensure timely and precise information on threats; elaboration of new methods of information collection and development of new warning procedures;

- Formulating a national position regarding possible participation in operations against terrorism out of the country's territory; specialization in certain capa- 
bilities to provide for effective contribution to counterterrorist operations in the framework of NATO. It is considered that through such specialization BAF will contribute effectively to the fight against international terrorism not only in NATO, but also in the framework of the United Nations and the European Union.

The BAF participation upon occurrence of terrorist acts is regulated in article 68 of the Law on Defense and Armed Forces. According to this article, in peacetime, when a "state of emergency" is declared, the armed forces can carry out tasks in support to civil authorities in their fight against the proliferation of weapons of mass destruction, illegal traffic of weapons and international terrorism. ${ }^{4}$ In addition, article 68 sets the roles of the armed forces as participants in the protection of "strategic sites" and in operations aimed at interrupting terrorist acts.

The Ministry of the Interior with its formations has the obligation to perform these tasks. The assumption is that the Bulgarian Armed Forces will be involved only in cases when the capacity of the Ministry of Interior is overwhelmed.

The roles of the armed forces are further elaborated in a set of counterterrorism tasks to be performed by the services:

- The Land Forces assist police units in reporting, blocking, neutralizing and clearing the areas which are targets of terrorism; they support the local authorities with modular units with capabilities to protect the population in cases of ecological crises, epidemics or industrial catastrophes caused by terrorist acts;

- The Air Force conducts observation, reconnaissance and defense of the air space and strategic sites; provides air support to other units of the armed forces participating in the fight against terrorism; provides support to other ministries and state agencies.

- Naval units monitor and protect harbor facilities and navigation devices in order to ensure safety of navigation, military and civilian coastal sites; in case of need, the Navy evacuates civilians injured or threatened by terrorist activities in the area of the Black Sea.

\section{Specifics in the Use of SOF in the Fight against Terrorism on National Territory}

The specific features in the use of Special Operations Forces (SOF) reflect the essence and the nature of our actions against modern terrorism. Let us recall three of the points made by the then NATO Secretary General in support of increasing the role of the military in the war on terrorism: 
First, ... the clear distinction between terrorism and warfare is fading. Today's terrorists aim to inflict mass casualties, and weapons of mass destruction are increasingly likely to fall into their hands. ...

The second reason for an important military role is that the distinction between internal and external security is fading. We used to be able to ensure external security by lining up tanks at the border, leaving internal security to our police forces. We can no longer rely exclusively on that division of labour. Terrorists can slip into our societies, and exploit our openness to inflict massive attacks - attacks that can require the expertise of the military to counter, or that have consequences that only the military can manage. It would be politically absurd not to use every capability at our disposal to deal with this new threat.

Thirdly, there is a military role because it will sometimes be impossible to protect our populations against terrorist attacks using defensive measures only. To prevent a clearly impending attack, or to respond to a successful attack, it may be necessary to deploy military assets offensively against terrorist networks, as in the case of Afghanistan. $^{5}$

Based on that, Lord Robertson made the following conclusion: “... the military has a vital part to play in the comprehensive international campaign to defeat terrorism. The mission of the last century-territorial defence-is out-of-date and out of place. We must radically redefine what the military is to do if we are to meet today's new challenges effectively." 6

As part of BAF, the Special Operations Forces have some unique characteristics that allow them to perform an important role in counterterrorist operations conducted by the armed forces. SOF units are effective, modular, compact, mobile, combat efficient, relatively independent and sustainable.

All national and territorial police services are directly or indirectly engaged in countering terrorism. Conducting operations for cutting off terrorist acts on the country's territory is the foremost responsibility of the Special Antiterrorist Unit and of the special units of the national services "Fight with Organized Crime," "Gendarmerie," and "Border Police." These organizations, which are part of the Ministry of the Interior, usually react first when there is a signal for terrorist activity and conduct the initial actions for seizing control over the situation.

In the circumstances of an escalating crisis, in order to restrain the crisis and not to allow its expansion, as well as to neutralize terrorist groups of considerable numbers, it is recommended, upon declaring a "state of emergency," to use SOF units without mobilizing all Immediate Reaction Forces of BAF. This is the SOF main role in counterterrorist operations.

When conducting operations of this kind, SOF will fulfill three types of tasks: 
- Antiterrorism - defensive measures for limiting the vulnerability to attacks against the population, the territory, the infrastructure and the information and communications infrastructure.

- $\quad$ Preventing terrorist assaults - offensive measures to reduce, prevent, and stop terrorist activities of subversive reconnaissance and terrorist groups.

- Control of the comprehensive set of activities for coping with the consequences of terrorist acts - provision of support to civilian authorities in constraining the impact and stabilizing the situation after such acts.

According to Lord Robertson, in order to accomplish these tasks it is necessary to build up security on the basis of something more than "perfect” plans and reporting diagrams. What we need is capabilities - the right capabilities. Among the priority capability requirements Lord Robertson listed the ability "to move quickly to deter, disrupt, defend or protect against terrorist attacks. With light, mobile forces. With sufficient strategic air and sea lift. With modern command, control, communications and intelligence. And with modern strike capabilities, such as precision guided munitions.” It also means having the equipment to detect any use of weapons of mass destruction, as well as to protect the forces operating in an environment where such weapons might be used. ${ }^{7}$

Training is also of paramount importance. There have been occasions when, even though the objective to eradicate terrorism has been well formulated, the use of disproportionate or inappropriate force in the absence of specialized training was ineffective or even counterproductive.

The armed forces should be capable, upon request, to provide assistance to national authorities in dealing with the consequences of terrorist attacks, particularly where these involve chemical, biological, radiological or nuclear weapons. Even more importantly, the armed forces are expected to deal with the threat at its origin. Therefore, as Lord Robertson observed, "military forces of yesterday-huge arsenals of battle tanks, static headquarters and inflexible soldiers-are not only useless in meeting these new threats. They also divert scarce defence resources away from urgent and pressing modernisation. That is simply inexcusable in today's security environment." ${ }^{8}$ It is necessary instead to develop quick reaction forces which can be deployed very quickly where needed in order either to carry out an attack or to respond to such attack with a more compact and mobile organization appropriate for the new missions. The build up of mobile, well-trained forces with advanced equipment is extremely important for the war on terrorism in the current security environment. Our military forces should receive proper training to carry out these new missions. They must learn to interact with civilian law-enforcement authorities, to respect the rights 
and to secure the trust of civilian populations, to serve not only as combatants, but also as constables and peacekeepers.

SOFs with their specific structure and mobility, with their comprehensive training, with the flexibility in their use, are closest to the above-mentioned requirements as elaborated in the speech of the then NATO Secretary General. SOFs are trained to participate in operations against terrorism, where they are expected to fulfill specific missions and tasks. Therefore, they must undergo a dedicated training in order to understand possible areas of operation, goals and tasks of terrorist organizations and their forces, the ways and the means used by these organizations in carrying out terrorist acts. More specifically, SOF headquarters and units conduct training to perform variety of tasks such as: reconnaissance and detection, pursuing and neutralizing leaders and formations of terrorist organizations; protection of VIPs and strategic sites of national and military importance to the country's security; limiting and isolating threatened areas, protecting the safety and preventing the spread of rumors and panic among the population; direct attacks against the terrorist infrastructure for the purpose of their neutralization or release of hostages.

The antiterrorist operation is a combination of objective-, task-, place- and time-coordinated activities, e.g., negotiations, search and investigative operations, conducted according to a common plan.

There are several types of antiterrorist operations. They may be classified according to the place of the operation, specific features of the participating forces, the time of reaction and the nature of the terrorist act or terrorist actions. We distinguish four main categories of operations:

- Hostage rescue operations are of highest degree of risk. They are conducted after elaborate planning and organization of the interaction among the forces participating in the operation. SOF isolate the area of activity and provide opportunity for the Special Antiterrorist Unit to rescue the hostage;

- Operations, conducted upon the occurrence of a terrorist act, such as securing a building, a vehicle, detonation of explosives, etc. This type of operations is characterized by the short time available for planning. Of particular importance are two additional features:

o The terrorists have initial advantage as a result of surprise;

o Wide variety of units with responsibilities for protection of public order or facilities takes part in the operation.

Depending on the place and time of a terrorist act, SOF can act independently for the elimination of the terrorists, or can block the area till the arrival of special antiterrorist units. 
- "Patrol operations" (like those in Northern Ireland, Southeast Turkey, Sicily, etc.) are conducted in areas under the control of "paramilitary organizations" and high terrorist threat. The objective in this type of operations is to restore the control over the territory which is partially (or for a definite period of time) in the hands of the "paramilitary" or terrorist organizations and to provide for normal functioning of the state authorities.

- Reconnaissance-searching operations are conducted in order to localize and capture single terrorists or terrorist groups. Special antiterrorist units and subversive reconnaissance units conduct this type of operations through combination of the methods used by SOF and investigative methods typical for police work.

Main purpose of all counterterrorist operations is the preservation of life and health of people and the defense of national and universal values. A typical characteristic of the antiterrorist operation is the fact that it is carried out under conditions of panic, stress, fear, endangered security, and considerable material losses, while the operation itself consumes tremendous resources.

The antiterrorist operations are conducted according to the following principles:

- Legitimacy. Any operation is carried out with awareness of and compliance with the norms of law. Soldiers and staff adhere strictly to legal regulations without going beyond their authority. Bearing in mind the specifics of terrorism, as well as the peculiar sensitivity of international institutions with respect to human rights, it is necessary to comply with the international agreements to which the Republic of Bulgaria is a party. SOF personnel must be familiar with the norms of behavior of the citizens of the country of operation, as well as foreign citizens residing in it. One purpose is that the actions of SOF would not be condemned by national and international courts.

- Purposefulness. The ultimate purpose of an operation is to contribute clearly and accurately to the accepted counterterrorist strategy. All subsequent actions follow a unified logic and a strict sequence towards achievement of the endstate, as envisaged in the strategy and provided for in the planning process. In order to combine the efforts of all units participating in the operation towards the achievement of its objectives, it is necessary that all command authorities are duly informed on these objectives through orders or directives.

- Effectiveness. The operation is accomplished through clearly assigned tasks; establishment and maintenance of effective communications; realistic assessment of the situation and the factors determining its development; optimum risk assessment and undertaking of adequate actions in response to situation development; avoidance of overlapping efforts through rational interaction; 
averting the scattering of resources through formation of mobile reserves of forces and means that would allow to gain control over situations in which the terrorists apply mock activities in an attempt to distract our attention and to spread our forces.

- Undivided authority. The antiterrorist operation is to be controlled by a single C2 center coordinating the actions of all participating forces. Operational command centers can be established within the area of the terrorist act, each of these under an authorized person with adequate powers.

- Security. Participating personnel is trained and equipped as to provide maximum protection. Security is further enhanced through risk assessment. The purpose is not to allow opportunities to imperil the forces participating in the operation.

- Support. Participating forces have the resources adequate for rendering the terrorists harmless and to eliminate the consequences of a terrorist act.

- Flexibility. When the situation in the crisis area changes, command authorities and participating forces are able to assess the situation adequately and to react promptly.

- Mobility. The C2 authority should have the capability to control the operation directly in the area of the crisis situation. That would assume capabilities to move quickly operational groups and detachments and their equipment, as well as the necessary communications and information systems.

- Maintenance of permanent readiness of the Special Operations bodies. Abrupt changes of the situations in the course of the operation are possible. Therefore, it might be necessary to quickly change the decision of the commanding officer in order to achieve the operational endstate.

- Tactical surprise. Giving the terrorists an opportunity to predict or decode the activities of the SOF teams can endanger the lives of both hostages and SOF personnel and, at the extreme, to failure of the whole operation.

- Constant impact on terrorists. In a hostage situation it is important to maintain permanent contact with the terrorists. That includes psychological and, if possible, visual contact.

- Concentration of the main forces on the most important targets (areas of responsibility).

\section{Planning the Antiterrorist Operation}

The antiterrorist operation is a higher organizational form of conducting operational and tactical activities by specially trained teams of the Special Operation Forces. It 
has two stages - preparation and action. The preparation of the antiterrorist operation in itself has two phases: preliminary preparation - before a terrorist act occurs, and immediate preparation - upon occurrence of the terrorist act.

The preliminary preparation is at the basis of effective counterterrorism. It includes a number of structured activities: obtaining the necessary information; analysis and assessment of possible targets of terrorist acts; provision of support; planning and training.

The collection of information from all possible sources is a decisive factor in determining the level of terrorist threat in a specific area, for a specific site or person. The Special Operation Forces receive such information through regular reports or upon request.

In order to determine the level of terrorist threat it is necessary to have information on:

- Local groups using terrorist methods, including information on their organization, leaders, number of members, specific features, established forms of action, and sponsors;

- External terrorist organizations having interests in the country - control center, structure, specific features and objectives, forms of activity and relations with local organizations;

- Results and analyses of the actions in both successful and unsuccessful special operations against terrorists, especially involving hostage taking, within the country and abroad;

- Domestic and international political, socio-economic or ethno-religious activities and trends that could influence the rise or fall of the terrorist threat.

Analysis and assessment of possible targets of terrorist acts is conducted continuously, with focus on:

- Determining of possible targets, classification of targets according to their importance, determining the level of terrorist threat, defining operational security and protective measures;

- Studying and documenting the technical and tactical characteristics and features of facilities under threat of terrorist acts. Updating, in a timely manner, of the related documentation, i.e., photographs, layouts, maps, blueprints, etc.;

- Developing scenarios (and courses of action) of likely terrorist attacks against the targets, as well as of possible ways of effective counteraction. 
In the course of the preliminary preparation of an operation against terrorists, support is provided through preventing or creating difficulties for terrorist activity via implementation of regular counter-measures in three directions: operational-tactical, personnel support, and technical support.

The operational-tactical provision includes the following:

- Clarifying the methods and techniques used by terrorist organizations for collection of reconnaissance information on possible targets, security systems and tactical groups for reaction in case of terrorist acts;

- Constant counteraction to terrorist intelligence through secrecy, disguise, misleading activities, and strict adherence to information sharing and protection measures according to the respective level of classification;

- Avoiding stereotypes in the approach to and the conduct of operations, in particular in the tactical planning of antiterrorist operations and incidents involving hostages.

The second type of support is the support to members of tactical groups and other counterterrorist units. A terrorist threat or attack can be directed against a person or against members of a specific group with or without an obvious reason. The terrorist threat can be demonstrated in a variety of forms - a telephone call, actions aimed at the persons themselves or against members of their family. Therefore, counter-measures are implemented continuously in order to:

- Determine and assess all possible threats, likely places and times of occurrence both in work-related and in family daily routine;

- Identify potential terrorist threats in a building, a car, an airplane or a public facility based on characteristic features or indicators of suspicious behavior;

- Conduct training for protection, counteraction and adequate reaction in the event of a terrorist attack in variety of circumstances and locations;

- Not to permit actions or behavior in everyday life (unless indispensable) that would reveal a person's affiliation with the security forces and tactical groups;

- Consistently use legal means, tactics and techniques for personal protection from non-disclosure of identity as tactical group members to protective vests, helmets and shields whenever necessary.

Preliminary planning and training are necessary to achieve good coordination of the efforts of various organizations and reliable control over all forces and means that could be used once a terrorist act has occurred. The preparation and the conduct of antiterrorist operations usually involve the state administration at various management levels, security forces and tactical groups. The preliminary planning provides to 
the organizations under threat of terrorist attack and the forces expected to react with an opportunity to prepare jointly countermeasures and to carry out a special operation. Thus, each organization is better prepared to exercise control in its area of responsibility and to act according to its internal organizational rules.

Drills and training exercises provide an additional opportunity to coordinate plans for interaction, to enhance command and control, to verify the effectiveness of tactical actions at various levels and, as a whole, to finalize the preliminary preparation of the Special Operation Forces for conducting antiterrorist operations. During this phase personnel and headquarters form the necessary skills and abilities to act in crisis situations. Training is of higher effectiveness when simulated situations and conditions are as realistic as possible.

The phase of immediate preparation is usually shorter; however, it should be comprehensive, covering: organization of the operation, tactical planning, preparation of the forces, deployment in the area of the operation, and organization of the interaction among the participating agencies. This phase starts when the SOF command receives a directive to prepare for actions against terrorists or to assist the structures of the Ministry of the Interior. It is also conducted once a "state of emergency" is announced. Most challenging are the conditions for immediate preparation in case terrorists have taken hostages. The two main reasons may be summarized as follows:

- In order to gain psychological superiority the antiterrorist operation must begin no later than two to four hours after the terrorist act;

- Often terrorists place time-related demands immediately after taking hostages. Such ultimatums have most serious, often fatal consequences and the timely reaction may be critical.

The Special Operation Forces would rarely act alone in conducting an antiterrorist operation.

The control of the antiterrorist operation is based on continuous collection of information on the situation and the condition of the terrorists, the course of the tactical actions and the results achieved, the assignment of additional tasks in changes of the situation, the establishment of conditions for good interaction among participating forces.

The conclusions drawn from the large-scale terrorist acts in the United States and the Russian Federation raised the issue of clear and accurate distribution of responsibilities and powers among the central executive powers and the local administration to make decisions in the course of an antiterrorist operation. Another set of questions addresses the adequacy of intelligence and counter-intelligence capabilities of national security systems, the establishment of a dynamic legal base for managing forces 
and other executive organizations, as well as the development of procedures for effective coordination and interaction among these organizations.

\section{Conclusion}

The current global security environment and the trends in its evolution provide sufficient grounds to assume that the role of the UN and NATO in resolving conflicts and managing threats to the world peace and security will be increasing.

The tragedy of September 11 turned into a fiasco for all special services and signified a serious breakthrough in the immune system of the democratic world. Pursuing their goals, the terrorists actively use the achievements of civilization and democracytechnological, information, political, financial, juridical—and in many cases more efficiently than the forces expected to counteract them.

A new, higher level of international cooperation is necessary, and Bulgaria is an indispensable part of the international response to terrorism. This country's contribution to the fight against terrorism will be growing in the years to come. The integration of the Republic of Bulgaria in the global coalition for stability, democracy and prosperity and its active participation in peace-keeping operations and the war on terrorism is motivated by the values that we share and the goals that we have - effective membership in NATO and the EU. This is the guarantee and the environment that will make our capacity greater and our contribution - more significant and more efficient.

\section{Notes:}

${ }^{1}$ Lord Robertson, NATO Secretary General, "The Role of the Military in Combating Terrorism" (Speech at the NATO-Russia Conference, Moscow, 9 December 2002), $<$ http://www.nato.int/docu/speech/2002/s021209b.htm> (19 Nov. 2005).

${ }^{2}$ For details refer to the Committee's website at http://www.un.org/sc/ctc/ (20 Nov. 2005). 
3 See for example Mark Weisbrot, “A War against Civilians?” Common Dreams News Center (2 November 2001), <http://www.commondreams.org/views01/1102-10.htm> (19 Nov. 2005).

4 Law on Defense and Armed Forces, State Gazette (December 1995), latest amendment as published in State Gazette 38 (May 2005). This particular text was amended in 2000.

5 Lord Robertson, "The Role of the Military in Combating Terrorism."

6 Lord Robertson, "The Role of the Military in Combating Terrorism."

7 Lord Robertson, "The Role of the Military in Combating Terrorism.”

8 Lord Robertson, "The Role of the Military in Combating Terrorism."

Colonel PLAMEN TORLAKOV is Commander of the $68^{\text {th }}$ Special Forces brigade in Plovdiv, Bulgaria. He is a graduate of the "Vasil Levski” Military Academy in Veliko Tarnovo (1982), the Command and Staff course of the "G.S. Rakovski” Defense and Staff College in Sofia, Bulgaria (1991) and the "General Staff” course of the same college (2003). He has served in a variety of command position in the Special Operations Forces. His distinguished military career includes service in the G2 Directorate of the Army Headquarters (1995-1999); Head of the Special Operations Directorate at J-2, General Staff of the Bulgarian Armed Forces (1999-2000); Head of the Special Operations and Electronic Warfare Directorate of the Army HQ. 